\title{
Risk Factors Analysis and Mapping of Pulmonary Tuberculosis in Community Health Centre Tamalatea of Jeneponto District
}

\author{
Irnawati Nur ${ }^{1}$, Nur Nasry Noor ${ }^{1}$, Andi Ummu Salmah ${ }^{2 \star}$, Anwar Mallongi ${ }^{3}$, Hasnawati Amqam² \\ ${ }^{1}$ Department of Epidemiology, Faculty of Public Health, Hasanuddin University, Makassar, Indonesia; ${ }^{2}$ Department of \\ Reproductive Health, Faculty of Public Health, Hasanuddin University, Makassar, Indonesia; ${ }^{3}$ Department of Environmental \\ Health, Faculty of Public Health, Hasanuddin University, Makassar, Indonesia
}

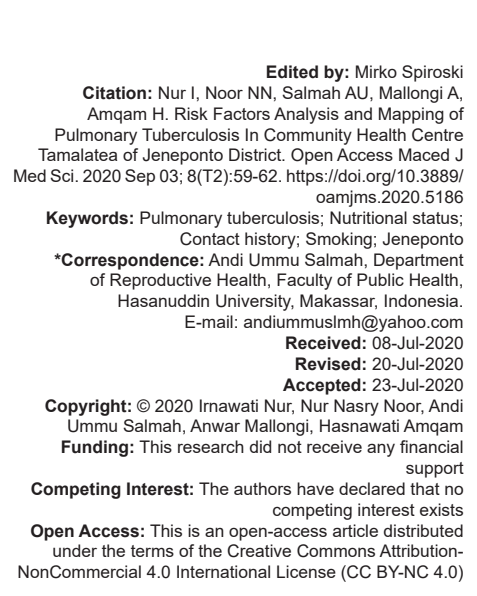

Abstract

BACKGROUND: Tuberculosis (TB) remains a global health problem, and in Indonesia, although TB control efforts have been carried out since 1995 . TB is ranked $9^{\text {th }}$ as the leading cause of death worldwide. The increase in the number of TB cases caused by risk factors triggering include a decrease in the immune system caused by HIV infection, nutritional status, education, sex, occupation, air humidity, house ventilation, temperature, occupancy density lighting, and contact history.

AIM: This study aimed to analyze the relationship of nutritional status, contact history, and smoking to the incidence of pulmonary TB in Community Health Centre Tamalatea of Jeneponto District.

METOHDS: This type of research is analytic observational with a case-control design with a total sample of 147 samples consisting of 49 cases and 98 controls. Data collection was conducted from August to October 2019. Data analysis used in the study was univariate and bivariate analysis with Chi-square test.

RESULTS: The results showed that nutritional status ( $O R=5.40395 \% \mathrm{Cl}: 2.547-11.461)$, contact history $(\mathrm{OR}=13.971$ $95 \% \mathrm{Cl}: 3.807-51.262)$, and smoking $(\mathrm{OR}=2.78295 \% \mathrm{Cl}: 1.370-5.648)$ are related to the incidence of pulmonary in Community Health Centre Tamalatea of Jeneponto District. TB officers are expected to intensify the home visit program, especially for pulmonary TB sufferers with a considerable distance from the community health center, with transportation constraints and relatively poor economic conditions so that the health status of pulmonary TB sufferers can be monitored properly.

CONCLUSION: TB officers are expected to intensify the home visit program, especially for pulmonary TB sufferers with a considerable distance from the Puskesmas, with transportation constraints and relatively poor economic conditions so that the health status of pulmonary TB sufferers can be monitored properly.

\section{Introduction}

Tuberculosis (TB) remains a global health problem, and in Indonesia, although TB control efforts have been carried out since 1995 . TB is ranked $9^{\text {th }}$ as the leading cause of death worldwide. In 2015, there were an estimated 10.4 million new TB cases and an estimated TB death of 1.4 million deaths. In 2016, there were also 10.4 million new TB cases and the death rate increased to 1.7 million deaths from TB compared to the previous year. Seven countries contributing $64 \%$ of TB cases in the world are India, Indonesia, China, the Philippines, Nigeria, Pakistan, and South Africa [1].

Data obtained from the Indonesian Health Profile in 2018 show that South Sulawesi is ranked $6^{\text {th }}$ province with the most TB cases in Indonesia. The number of positive smear pulmonary TB cases in South Sulawesi Province in 2018 was 7958 cases. TB in South Sulawesi Province in 2018 was 75 per 100,000 population and case notification rate TB. The positive smear lung is 267 per 100,000 population [2].
Based on data from the Jeneponto District Health Profile, the number of TB cases in the past 3 years tends to increase. In 2016, there were 440 cases reported, in 2017452 cases, and in 2018, there were an increase of 551 cases. Tamalatea District is the largest contributor to the number of TB cases in Jeneponto Regency with 49 positive BTA cases [3].

The result of Fitriani's study [4] states that the rate of TB transmission in the family environment is quite high and an average patient can transmit it to people in his house, while the risk of transmission to households with TB sufferers $>1$ person is 4 times higher than that of the home stairs with one person with TB. According to Narasimhan et al. [5], TB risk factors include a decrease in the immune system caused by HIV infection, nutritional status, education, sex, occupation, air humidity, house ventilation, temperature, occupancy density lighting, and contact history.

The results of Supriyono et al. [6] study in Pekalongan City stated that the risk of pulmonary TB occurring in people with poor nutritional status was 7.5 times greater than that of people with good nutritional 
status $(\mathrm{OR}=7.5 ; 95 \% \mathrm{Cl}=3.406-16.882 ; \mathrm{p}<0.001)$. However, the study of Chen et al. [7] in rural China found that a history of contact with TB patients was not a risk factor for TB transmission. Nurjana's research results [8] concluded that the risk factor for pulmonary TB in the productive age is the level of education because the level of education will affect one's knowledge about pulmonary TB.

Geographic information systems (GISs) are good tools for improving understanding of data through visualization and analysis. GIS is used by public health professionals to make planning, monitoring, and surveillance. Displaying data in the form of maps are able to provide more insight than table forms with the same data. The map is able to display a rapid assessment of trends and relationships [9]. The general objective of this study was to assess the risk of nutritional status, history of contact, and smoking to the incidence of pulmonary TB and the mapping of the distribution of pulmonary TB cases in the work area of the Tamalatea Health Center in Jeneponto Regency.

\section{Materials and Methods}

This research was conducted in Community Health Centre Tamalatea of Jeneponto District, South Sulawesi Province. This research was an observational analytic study using a case-control study design, which is a study by comparing cases and control groups based on their exposure status through retrospective observations by studying the dynamics of the relationship of risk factors with pulmonary TB events who visited the Community Health Centre Tamalatea of Jeneponto District.

Respondents in this study were all patients aged $\geq 15$ years, who suffered or did not suffer from pulmonary TB (+) and were recorded in the TB register and outpatient at the Tamalatea Health Center in Jeneponto Regency. The total sample in this study was 147 respondents consisting of 49 case respondents and 98 control respondents. Case respondents in this study were patients aged $\geq 15$ years who suffered from BTA lung TB (+) and were recorded in the TB register and control respondents were patients $\geq 15$ years who did not suffer from BTA Lung TB (+) and were recorded in the outpatient register.

Data collection is done by means of observation and interviews. The type of data collected in this study is primary data and secondary data. Primary data collection uses a research instrument in the form of a questionnaire used in interviews with respondents while the secondary data are obtained from the TB register of the health office, the results of hospital laboratory examinations, TB registers, and Puskesmas outpatient registers.
Analysis of the data used is univariate and bivariate analysis. Bivariate analysis uses the Chisquare test to assess the relationship between the independent variable and the dependent variable.

\section{Results}

Table 1 shows the characteristics of respondents by age group, the most cases occurred at age $26-33$ years $(24.5 \%)$ and the most control group was at age 26-33 years $(22.9 \%)$ and at age $34-41$ years $(22.9 \%)$. The education level of respondents in the case and control groups was more in the category of not completing elementary school, respectively, $34.7 \%$ and $22.9 \%$. However, the proportion of respondents not attending school was found to be more prevalent in the case group (28.6\%) compared to the control group (10.4\%). Based on work, in the case and control groups, most of the housewives were $38.8 \%$ and $27.1 \%$, respectively.

Table 2 shows that based on nutritional status, the proportion of malnutrition was found to be greater in cases $(71.4 \%)$ than in controls $(31.6 \%)$. Variable contact history TB, the proportion of no more contacts found in both cases $(69.4 \%)$ and controls (96.9\%). However, the proportion of contacts was more common in cases $(30.5 \%)$ compared to controls $(3.1 \%)$. Based on smoking variables, the group of cases more smoked (55.1\%) compared to controls $(30.6 \%)$.

The bivariate test results between the independent variables and the dependent variable in this study are shown in Table 3. The analysis results for the gizi status variable obtained the value $\mathrm{OR}=5.403$ (95\% Cl: 2.547-11.461), contact history OR=13.971 (95\% Cl: 3.807-51.262), and smoking OR=2.782 (95\% Cl: 1.370-5.648) statistically significant for the incidence of pulmonary in Community Health Centre Tamalatea of Jeneponto.

Table 1: Distribution of general respondents characteristics

\begin{tabular}{llllll}
\hline Characteristics & \multicolumn{2}{c}{ Case $(\mathrm{n}=49)$} & & \multicolumn{2}{c}{ Control $(\mathrm{n}=98)$} \\
\cline { 2 - 3 } \cline { 5 - 6 } & $\mathrm{n}$ & $\mathrm{n}$ & & $\%$ \\
\hline Age (years) & 8 & 16.3 & & 16 & 16.7 \\
$18-25$ & 12 & 24.5 & & 22 & 22.9 \\
$26-33$ & 10 & 20.4 & & 22 & 22.9 \\
$34-41$ & 6 & 12.2 & & 12 & 12.5 \\
$42-49$ & 2 & 4.1 & & 6 & 6.3 \\
$50-57$ & 8 & 16.3 & & 14 & 14.6 \\
$58-65$ & 3 & 6.1 & & 6 & 6.3 \\
66-73 & & & & \\
Primary school & 14 & 28.6 & & 10 & 10.4 \\
Uneducation & 17 & 34.7 & & 22 & 22.9 \\
Unfinished primary school & 3 & 6.1 & & 21 & 21.9 \\
Primary school & 7 & 14.3 & & 15 & 15.6 \\
Junior high school & 6 & 12.2 & & 20 & 20.8 \\
Senior high school & 2 & 4.1 & & 10 & 10.4 \\
Bachelor & & & & \\
Job & 19 & 38.8 & & 26 & 27.1 \\
Housewives & 4 & 8.2 & & 4 & 4.2 \\
Laborer & 17 & 34. & & 17 & 17.7 \\
Farmer & 4 & 8.2 & & 23 & 24 \\
Entrepreneur & 1 & 2 & 10 & 10.4 \\
Civil servant & 4 & 8.2 & 16 & 16.7 \\
Others & & & & \\
\hline
\end{tabular}




\section{Discussion}

The results of the bivariate analysis in this study found that nutritional status, contact history, and smoking risked the incidence of pulmonary TB in the working area of the Tamalatea Health Center in Jeneponto Regency.

Table 2: Distribution of respondents based on research variables

\begin{tabular}{llllll}
\hline Variables & \multicolumn{2}{l}{ Case $(\mathrm{n}=49)$} & & \multicolumn{2}{c}{ Control $(\mathrm{n}=98)$} \\
\cline { 2 - 3 } & $\mathrm{n}$ & $\%$ & & \\
\hline Nutritional status & 35 & 71.4 & & 31 & 31.6 \\
$\quad$ Less & 14 & 28.6 & & 67 & 68,4 \\
$\quad$ Good & & & & \\
Contact history & 15 & 30.6 & & 3 & 3.1 \\
$\quad$ There is contact & 34 & 69.4 & & 95 & 96.9 \\
$\quad$ No contact & & & & \\
Smoking & 27 & 55.1 & & 30 & 30.6 \\
$\quad$ Smoking & 22 & 44.9 & 68 & 69.4 \\
$\quad$ No smoking & & & & \\
\hline
\end{tabular}

Table 3: Distribution of independent variable risk for incidence of pulmonary TB in Community Health Centre Tamalatea of Jeneponto district

\begin{tabular}{|c|c|c|c|c|c|}
\hline \multirow[t]{2}{*}{ Variables } & \multicolumn{2}{|c|}{ Case $(n=49)$} & \multicolumn{2}{|c|}{ Control $(n=98)$} & \multirow[t]{2}{*}{$\mathrm{Cl} 95 \%$} \\
\hline & $\mathrm{n}$ & $\%$ & $\mathrm{n}$ & $\%$ & \\
\hline \multicolumn{6}{|l|}{ Nutritional status } \\
\hline Less & 35 & 71.4 & 31 & 31.6 & \multirow[t]{2}{*}{$2.547-11.461$} \\
\hline Good & 14 & 28.6 & 67 & 68.4 & \\
\hline \multicolumn{6}{|l|}{ Contact history } \\
\hline There is contact & 15 & 30.6 & 3 & 3.1 & \multirow[t]{2}{*}{$3.807-51.262$} \\
\hline No contact & 34 & 69.4 & 95 & 96.9 & \\
\hline \multicolumn{6}{|l|}{ Smoking } \\
\hline Smoking & 27 & 55.1 & 30 & 30.6 & \multirow[t]{2}{*}{$1.370-5.648$} \\
\hline Not smoking & 22 & 44.9 & 68 & 69.4 & \\
\hline
\end{tabular}

Based on the nutritional status of respondents, it was found that the proportion of nutrients was less greater in cases $(71.4 \%)$ than in controls $(31.6 \%)$. Statistical test results obtained from the nutritional status variable value of $\mathrm{OR}=5.403(95 \% \mathrm{Cl}$ : $2.547-11.461)$ with lower limit and upper limit values (LL-UL) that do not include a value of 1 . This means that nutritional status is a risk factor $(\mathrm{OR}=5,403)$ which is statistically significant for the incidence of pulmonary TB so it can be concluded that people with nutritional status are less at risk of suffering from pulmonary TB by 5.403 times compared to people with good nutritional status.

The results of this study are in line with research conducted by Oktavia et al. [10] which shows that the proportion of underweight respondents' nutritional status (body weight less than body mass index) in the case group was $81.8 \%$ while in the control group was $21.2 \%$. The proportion in the case group was almost 4 times that of the control group. Statistical test results obtained an OR value of $16.7(95 \% \mathrm{Cl}$ 4.95-56.39), meaning that people with poor nutritional status increase the risk of developing lung TB 16.7 times compared to respondents with normal/excessive nutritional status. $p=0.001$ concluded that there was a statistically significant relationship between nutritional status and the incidence of pulmonary TB.

The results of the study by Supriyono et al. [6] showed that the statistical test results obtained $\mathrm{p}=0.230$ and $\mathrm{OR}=7.583$ with $95 \% \mathrm{Cl}=3,406<\mathrm{OR}$ $<16,882$, thus stated that nutritional status is a risk factor for pulmonary TB events or there is a relationship between status nutrition with the incidence of pulmonary TB. This means that someone with nutritional status has a risk of increasing the incidence of pulmonary TB as much as 7.583 times greater than with good nutritional status.

Nutritional status is one of the factors that determine the function of the entire body system including the immune system. If the immune system is strong, then the germs will continue to sleep in the body (dormant) and do not develop into a disease but if the immune system is weak, the TB germs will develop into a disease. Pulmonary TB disease is more dominant in people with low nutritional status because of a weak immune system, making it easier for TB germs to enter and multiply [11].

Based on the contact history of TB respondents, the proportion of no more contacts was found in both cases $(69.4 \%)$ and controls $(96.9 \%)$. However, the proportion of contacts was more found in cases $(30.5 \%)$ compared to controls (3.1\%). The statistical test results of TB contact history obtained OR value $=13.971(95 \%$ $\mathrm{Cl}$ : 3.807-51.262) with LL-UL which do not include a value of 1 , this means that a contact history of TB is a risk factor $(O R=13.971)$ which is statistically significant for pulmonary TB events so that it can be concluded that people who have a history of contact with TB sufferers the risk of suffering from pulmonary TB by 13,971 times compared to people with no history of contact with TB sufferers.

Research by Butiop et al. [12] shows the results of statistical analysis using the Chi-square test on variable household contact factors with the incidence of pulmonary $\mathrm{TB}, \mathrm{p}<0.05$ means that there is a significant relationship between the history of household contact with the incidence of pulmonary TB. The odds ratio value of 3.848 means that the probability for the occurrence of pulmonary TB in a positive household contact factor is about 3.8 times higher than the negative household contact factor.

Based on the smoking habits of the respondents, more group groups smoked (55.1\%) compared to controls $(30.6 \%)$. Statistical test results obtained by smoking variable OR value=2.782 $(95 \%$ $\mathrm{Cl}: 1.370-5.648)$ with LL-UL values that do not include a value of 1 . This means that smoking is a risk factor $(O R=2.782)$ which is statistically significant for the incidence of pulmonary TB so that it can be concluded that respondents with a history of smoking are at risk of suffering from pulmonary TB by 2.782 times compared to respondents who do not have a history of smoking.

The results of Hita et al. [13] show that data analysis using the Spearman rank test obtained $p=0.000$, meaning that there is a significant relationship between cigarette consumption and the incidence of TB in Kawangu Health Centre, Pandawai District, East Sumba Regency, East Nusa Tenggara Province [14], [15]. 


\section{Conclusion}

TB officers are expected to intensify the home visit program, especially for pulmonary TB sufferers with a considerable distance from the Puskesmas, with transportation constraints and relatively poor economic conditions so that the health status of pulmonary TB sufferers can be monitored properly.

\section{References}

1. World Health Organization. Global Tuberculosis Control Report. Geneva: World Health Organization; 2017.

2. Kemenkes RI. Profil Kesehatan Indonesia Tahun 2017. Jakarta: Kementerian Kesehatan Republik Indonesia; 2018.

3. Jeneponto D. Profil Kesehatan Jeneponto Tahun 2018 Jeneponto: Dinas Kesehatan Jeneponto; 2019. https://doi. org/10.32382/medkes.v14i2.1112

4. Fitriani E. Faktor risiko yang berhubungan dengan kejadian tuberkulosis paru. UNNES J Public Health. 2013;2(1):1-6.

5. Narasimhan P, Wood J, Raina MC, Mathai D. Risk factors for tuberculosis. Pulm Tuberc. 2013(8):1-11.

6. Supriyono, Baequni A, Hidayati S, Hartono M, Harnany AS. Pengaruh perilaku dan status gizi terhadap kejadian tb paru di kota pekalongan. Pena Med J Kesehatan. 2013;4(1):1-8. https://doi.org/10.33475/jikmh.v6i1.65

7. Chen W, Shu W, Wang M, Hou Y, Xia Y, Xu W, et al. Pulmonary tuberculosis incidence and risk factors in rural areas of China: $A$ cohort study. PLoS One. 2013;8(3):1-7. https://doi.org/10.1371/ journal.pone.0058171

8. Nurjana MA. Faktor risiko terjadinya tuberkulosis paru usia produktif (15-49 Tahun) di Indonesia. Med Litbangkes. 2015;25(3):165-70.

9. Fisher RP, Myers BA. Free and simple GIS as appropriate for health mapping in a low resource setting: A case study in eastern Indonesia. Int J Health Geogr. 2011;10(15):1-15. https:// doi.org/10.1186/1476-072x-10-15

10. Oktavia S, Mutahar R, Destriatania S. Analisis faktor risiko kejadian tb paru di wilayah kerja puskesmas kertapati Palembang. J IImu Kesehatan Masyarakat. 2016;7(2):124-38. https://doi.org/10.26553/jikm.2016.7.2.124-138

11. Damayati DS, Susilawaty A, Maqfirah. Risiko kejadian tb paru di wilayah kerja puskesmas liukang tupabbiring kabupaten pangkep. J Kesehatan Lingkungan. 2018;4(2):121-30. https:// doi.org/10.36568/kesling.v12i1.50

12. Butiop HM, Kandou GD, Palandeng HM. Hubungan kontak serumah, luas ventilasi, dan suhu ruangan dengan kejadian tuberkulosis paru di desa wori, Manado. J Kedokt Komunitas Tropik. 2015;3(4a):241-8. https://doi.org/10.33377/jkh.v2i1.59

13. Hita PM, Hariyanto $T$, Lasri. Hubungan antara konsumsi rokok dengankejadian penyakit tuberculosis (TBC) di puskesmas kawangu kecamatan Pandawai Kabupaten Sumba Timur Provinsi Nusa Tenggara Timur. J Ilmiah Mahasiswa Keperawatan. 2017;2(3):240-50. https://doi.org/10.33701/ jt.v8i2.619

14. Birawida $A B$, Selomo $M$, Mallongi A. Potential hazards from hygiene, sanitation and bacterium of refill drinking water at Barrang Lompo island (water and food safety perspective). IOP Conf Earth Environ Sci. 2018;57(1):012034. https://doi. org/10.1088/1755-1315/157/1/012034

15. Mallongi A, Parkpian $P$, Pataranawat $P$, Chinwetkitvanich $S$. Mercury distribution and its potential environmental and health risks in aquatic habitat at artisanal Buladu gold mine in Gorontalo Province, Indonesia. Pak J Nutr. 2015;14(12):101025. https://doi.org/10.4028/www.scientific.net/amr.931-932.744 